\title{
Serological Detection of Newcastle Disease Virus Antibodies in Local Chickens and Guinea Fowls in the Area of Kumasi, Ghana
}

EAuthor(s)

\author{
Boakye OD' \\ Emikpe $\mathrm{BO}^{\mathrm{IV}}$ \\ Folitse RD' \\ Bonnah SGI \\ Adusei $\mathrm{K}^{\mathrm{II}}$ \\ Owusu $\mathrm{M}^{\prime}$ \\ Oyebanji VO'
}

School of Veterinary Medicine, Kwame Nkrumah University of Science and Technology

" Ministry of Food and Agriculture, Veterinary Service Department

III Veterinary Investigations Laboratory, Kumasi.

IV Department of Veterinary Pathology, University of Ibadan, Nigeria

\section{Mail Address}

Corresponding author e-mail address Benjamin Emikpe

Department of Pathobiology, School of Veterinary Medicine, Kwame Nkrumah

University of Science and Technology,

Kumasi, Ashanti, Ghana - 0233

Phone: (+233) 549410841

Email: banabis2001@yahoo.com

\section{-Keywords}

Haemagglutination Inhibition test, Newcastle Disease, Vaccine, Kumasi, Ghana.

\section{ABSTRACT}

Newcastle Disease (ND) has been identified as a major constraint to local poultry production with its impact being felt more in rural poultry production which forms about $80 \%$ of Ghana poultry population. However documented evidence on ND virus activity in rural poultry in Ghana is still lacking. Hence, this study was conducted to evaluate the level of circulating antibodies against ND using the Haemagglutination Inhibition (HI) technique. Sera collected from unvaccinated 292 chickens and 153 guinea fowls randomly selected from households and a live bird market in Kumasi and its environs were evaluated for Newcastle disease virus antibodies. Results showed $81.8 \%$ (239/292) of local chickens and $24.2 \%$ (37/153) of guinea fowls tested positive for ND antibodies. Comparison was made between the seroprevalence of ND antibodies in household and live bird market as well as between sexes. Significantly higher prevalence rate $(p<0.05)$ was observed with chickens sampled from households compared to those from the live bird market. Higher ranges of titers were also observed in chickens from households than those from live bird markets. The presence of ND antibodies in these unvaccinated local chickens and guinea fowls indicated the presence of the virus amongst the rural poultry population, hence aneed for improvement in vaccine campaignand delivery against ND for rural poultry especially with the use of thermostable and improved oral or feed-based vaccine delivery systems.

\section{INTRODUCTION}

Poultry production is the fastest growing component of global meat production, with developing and transitional countries assuming a leading role (Assa, 2012). As indicated by Rojendran \& Mohanty, (2003), poultry farming has become foremost among the subsidiary occupations of farmers to supplement their incomes because it assures quick returns, requires minimum space and investment, and can be carried out by ordinary farmers. In Ghana, the poultry industry is an important source of income and sustenance of livelihood for many individuals and families. Chicken eggs and meat are major sources of animal protein in the Ghanaian diet and their importance cannot be over-emphasized. This was reflected in the Veterinary Services Directorate (VSD) report for the year 2009, which showed that the poultry population of Ghana was slightly over 36.2 million, with local chicken forming $13.92 \%$ and guinea fowls $7.10 \%$ of the national total poultry population (VSD Annual reports, 2010). There is an increasing demand for chicken and chicken products in the Ghanaian market, which, coupled with an inadequate domestic production, determined a large volume of imports from other parts of the world. In 2010, while domestic production was estimated in 37,279 tones of chicken 
Boakye OD, Emikpe BO, Folitse RD, Bonnah SG, Adusei K, Owusu M, Oyebanji vo

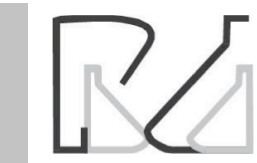

meat, the official figure of imported chicken meat was recorded as 72,418tonnes (VSD, 2011). However, local poultry industry in the country has been hampered by numerous conditions including diseases, high cost of feed and medication, as well as competition with cheaper imported frozen chicken products from the European markets (Aning, 2006) and elsewhere.

Newcastle Disease has been identified as a major impediment to national poultry production particularly among the rural poultry population (Bensink \& Spradbow, 1999) in Ghana. Also, about $80 \%$ of the annual mortality of rural poultry has been attributed to outbreaks of Newcastle disease (VSD, 1998), which are unpredictable and often discourage villagers from paying proper attention to the husbandry and welfare of their chickens (Alders \& Spadbrow, 2000). In 2013, the annual report of the Veterinary Investigations Laboratory, Kumasi also recorded 97 different cases of Newcastle disease, in which a total of 2,509 birds diedand 334,006 of commercially-housed birds were exposed. However, there is dearth of information in Ghana on the activity of the Newcastle disease virus in rural poultry population and chickens from live bird markets, which have been identified to be often involved in the spread of the disease (Spradbrow, 1988). The Government of Ghana recently launched poultry projects aimed at boosting local poultry production and empowering livelihoods, especially in the rural communities where these projects are located, and therefore, the need to understand the ND virus activity in rural poultry population in backyard and small-scale poultry farms is crucial. This investigation evaluates the activity of the Newcastle disease virus in local chicken and guinea fowl populations in live bird markets and households in Kumasi and its environs.
Serological Detection of Newcastle Disease Virus Antibodies in Local Chickens and Guinea Fowls in the Area of Kumasi, Ghana

\section{MATERIALS AND METHODS}

\section{Study area}

The study was conducted in Kumasi Central Market in the Kumasi Metropolis and Ejisu Municipality, both in the Ashanti Region of Ghana. The Ashanti Region includes one (1) Metropolitan, six (6) Municipal and twenty (20) District Assemblies. The total land area is 24,389 square kilometers with the regions surrounding the Ashanti capital Kumasi having a population of 11 million Ashanti's (Ajani \& Ocobock 2012). The southern districts lies in thehumid semi-deciduous forest, whilst the Guinea savannah covers the northern part. The administrative capital is Kumasi. The Kumasi Metropolitan area has an approximate area of 254 square kilometers and it is located between latitudes $60^{\circ} 35^{\prime \prime}$ and $60^{\circ} 4^{\prime \prime} \mathrm{N}$ and longitudes 10 $30^{\prime \prime}$ and $10^{\circ} 35^{\prime \prime}$ E. It shares boundaries with the Kwabre District to the north, AtwimaKwanwoma and AtwimaNwabiagya District to the west, Ejisu-Juaben Municipal to the east and Bosomtwe District to the south (Ghana Statistical Service, 2006).

The Ejisu-Juaben Municipality lies within Latitudes $1^{\circ} 15^{\prime} \mathrm{N}$ and $1^{\circ} 4^{\prime} \mathrm{N}$ and Longitude $6^{\circ} 15^{\prime} \mathrm{W}$ and $7^{0} 00^{\prime} \mathrm{W}$, occupying a land area of $582.5 \mathrm{~km}^{2}$. The Municipality lies in central part of the Ashanti Region, sharing boundaries with six Districts in the Region. The district capital is sited at Ejisu (Ghana Statistical Service, 2014).

\section{Study design}

Multistage sampling was carried out using stratified random sampling. The three regions where poultry populations are high in Ghana were listed. They are BrongAhafo, Ashanti, and Greater

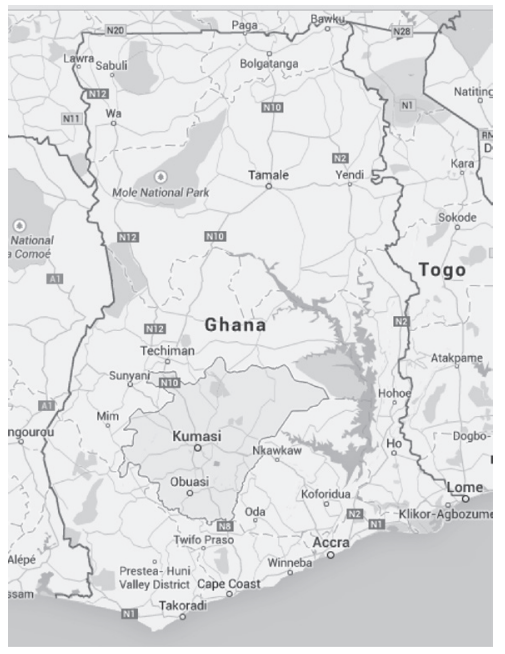

Figure 1a: Map of Ghana

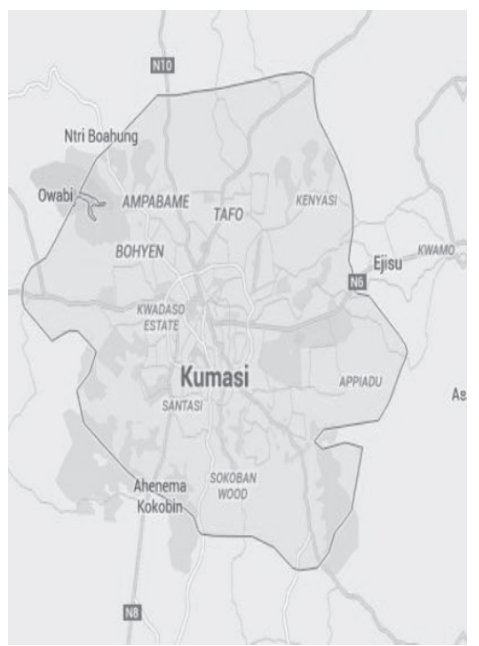

Figure 1b: Map of Kumasi

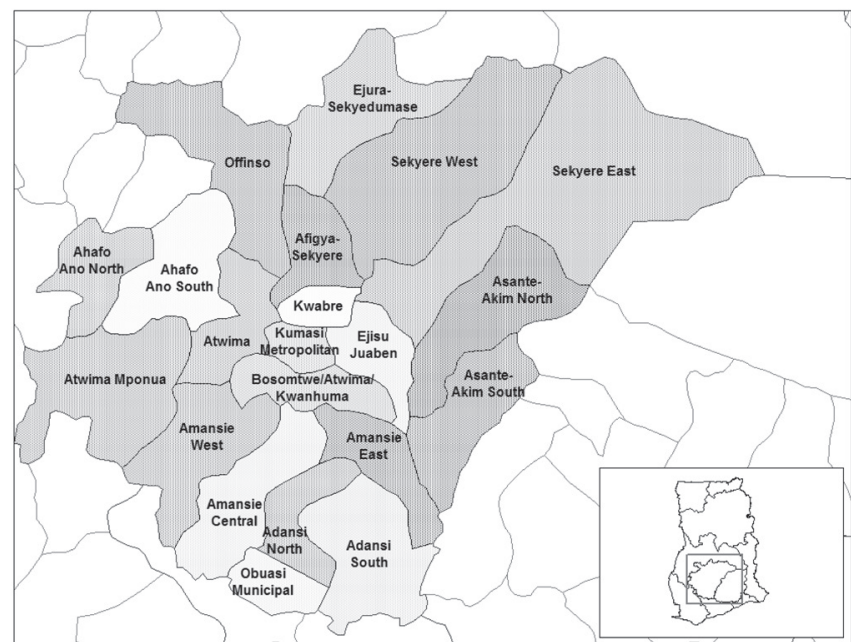

Figure 1c: Map of Ashanti Region 
Boakye OD, Emikpe BO, Folitse RD, Bonnah SG, Adusei K, Owusu M, Oyebanji vo

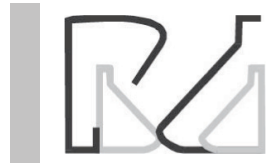

Accra Region (Fig 1a,b,c). A random selection was made andthe Ashanti Region was chosen. In the Ashanti region, districts which also have some of the highest poultry populations were identified. They are Atwima-Nwabiagya, Kumasi, and EjisuJuaben districts. Two districts were then randomly selected, and the Kumasi and Ejisu-Juaben districts were chosen. In Kumasi, areas in which local fowls and guinea fowls are likely to be concentrated were identified. The Kumasi Central Market was chosen. The Kumasi Central Market is main destination for commercial transactions of local chickens brought in from Kumasi city and other areas. In selecting the birds, a systematic random sampling was made, and each bird on the $5^{\text {th }}$ count was selected.

At Ejisu-Juaben district, the towns in which the local chickens were concentrated were identified to be Besease, Juaben, Adumasa and Pokuase. A list of these townships was made and Besease and Adumasa townships were randomly selected. In the towns, a house was selected on each third count and 3-5 birds were randomly selected by the householders themselves. A verbal interview was conducted. The selected birds were then sampled taking 3-5 $\mathrm{mL}$ of blood from the wing vein using a sterile $5 \mathrm{~mL}$ syringe, which was emptied into a clean test tube and keptat room temperature for 5-6 hours. The tubes were then labeled appropriately, indicating fowl type and sex. The sera were collected and stored under $-20^{\circ} \mathrm{Cin}$ Eppendorf tubes. Haemagglutination Inhibition test was then performed using the OIE standard protocol. Briefly, $0.025 \mathrm{~mL}$ of PBS was dispensed into each well of a plastic V-bottomed microliter plate then 0.025 $\mathrm{mL}$ of serum was placed into the first well of the plate. Two-fold dilutions of $0.025 \mathrm{~mL}$ serum were then made across the plate. ND viral antigen $(0.025$ $\mathrm{mL}$ )was added to each well and the plate was left for 30 minutes at room temperature. Chicken Red Blood Cells (RBCs) $0.025 \mathrm{~mL}$ of $1 \%(\mathrm{v} / \mathrm{v}))$ was then added to each well and, after gentle mixing, the
Serological Detection of Newcastle Disease Virus Antibodies in Local Chickens and Guinea Fowls in the Area of Kumasi, Ghana

RBCs were allowed to settle for about 30 minutes at room temperature. The agglutination is assessed by tilting the plates with those wells in which the RBCs streaming was observed at the same rate as the control wells (positive serum, virus/antigen and PBS controls) considered to show inhibition.

\section{Data Analysis}

Microsoft Excel 2010 spreadsheet was used to categorize the data and calculate the geometric mean titers. The HI data obtained were submitted toanalysis of variance using the SPSS package version 16 . Categorical variables (sex, location, bird type, place of purchase) were evaluated using the Chi-square test at $95 \%$ confidence interval to measure the strength of association among variables. Values of $p<0.05$ were considered significant.

\section{Results}

The interviews conducted revealed that the birds were usually not vaccinated, as the last vaccination reported by the farmers was in 2011 . The interview also showed that women and children were those most involved in rural poultry production. It also revealed that farmers recognized the clinical features (e.g. torticollis, high mortality, etc.) associated with ND with periodic outbreaks often experienced during the dry season.

Table 1 shows birds from households presented higher prevalence of ND than those collected in the market. In Ejisu- Besease, 83.3\% females from tested positive while all (100\%) males werepositive. In EjisuAdumasa, the prevalence in females was higher (98.4\%) than that recorded at Ejisu-Besease, while the same situation (100\%) was observed in males from the two areas. Female guinea fowls presented a prevalence of $25.7 \%$, while males had a prevalence of $22.9 \%$. However, the mean titers of the positive males were lower compared with those positive females, although not statistically significant.

Table 1 - Prevalence of Newcastle disease antibodies in local chickens and guineafowls from various locations in Kumasi and its environs

\begin{tabular}{|c|c|c|c|c|c|c|c|}
\hline \multirow[t]{2}{*}{ LOCATION } & \multicolumn{7}{|c|}{ Numbers of chickens } \\
\hline & Total & Females(f) & Males(m) & $\mathrm{F}(+)$ & Titer & $M(+)$ & Titer \\
\hline Kumasi Central Market & 57 & $24(42.1 \%)$ & $33(57.9 \%)$ & $12(50 \%)$ & 5.2 & $6(18.2 \%)$ & 5.6 \\
\hline Ejisu- BeseaseHousehold & 85 & $72(84.7 \%)$ & $13(15.3 \%)$ & $60(83.3 \%)$ & 6.3 & $13(100 \%)$ & 7.7 \\
\hline Ejisu-AdumasaHousehold & 150 & $126(84.0 \%)$ & $24(16.0 \%)$ & $124(98.4 \%)$ & 9.8 & $24(100 \%)$ & 11 \\
\hline \multirow[t]{2}{*}{ Total } & 292 & $222(76.0 \%)$ & $70(24.0 \%)$ & $196(88.3 \%)$ & 8.2 & $43(61.4 \%)$ & 9.0 \\
\hline & \multicolumn{7}{|c|}{ Numbers of guineafowls } \\
\hline Kumasi Central Market & 153 & $70(45.8 \%)$ & $83(54.2 \%)$ & $18(25.7 \%)$ & 6.9 & $19(22.9 \%)$ & 5.4 \\
\hline
\end{tabular}


Table 2 - The ND titer ranges of local chicken and guinea fowls obtained from household and live bird markets in Kumasi, Ghana.

\begin{tabular}{|c|c|c|c|c|c|c|}
\hline \multirow[t]{2}{*}{ BIRD TYPE } & \multirow[t]{2}{*}{ AREA OF ACQUISITION } & \multicolumn{4}{|c|}{ NEWCASTLE TITERRANGE $\left(\log _{2}\right)$} & \multirow[b]{2}{*}{ Total } \\
\hline & & 0 & $1-5$ & $6-10$ & ABOVE 10 & \\
\hline \multirow[t]{2}{*}{ Guinea fowl } & Market & 116 & 12 & 21 & 4 & 153 \\
\hline & & $75.8 \%$ & $7.8 \%$ & $13.7 \%$ & $2.6 \%$ & $100.0 \%$ \\
\hline \multirow[t]{2}{*}{ Local chicken } & Market & 40 & $6^{a}$ & $8^{c}$ & $3^{e}$ & 57 \\
\hline & & $70.2 \%$ & $10.5 \%$ & $14.0 \%$ & $5.3 \%$ & $100.0 \%$ \\
\hline \multirow[t]{2}{*}{ Local chicken } & Household & 14 & $19^{b}$ & $74^{d}$ & $128^{f}$ & 235 \\
\hline & & $6.0 \%$ & $8.1 \%$ & $31.5 \%$ & $54.5 \%$ & $100.0 \%$ \\
\hline
\end{tabular}

$p$ Value $=0.05,{ }^{*}$ values with different superscript indicates statistical difference $(p<0.05)$

Table 2 shows that the titer ranges of birds from the householdsaresignificantly different from those of from those obtained in themarket. It also showed various titer ranges of both local chicken and guinea fowls, where the birds that tested negative or had no detectable ND antibodies were designated 0 , and those that tested positive were grouped 1-5, 6-10 and above $10\left(\log _{2}\right)$. Most of the local chickens from households presented titers higher than $6 \log _{2}$, whereas around $70 \%$ of those in the market were negative. The guinea fowls obtained in the market presented antibody titer distribution similar to that of the local market chickens.

\section{DISCUSSION}

This serological study revealed the presence of circulating antibodies of Newcastle disease (ND) among local chickens and guinea fowls in Kumasi and its environs, with $81.8 \%$ of local chicken and $24.2 \%$ of guinea fowls tested positive. This shows that ND is still an endemic viral disease of rural poultry in Ghana, as earlier observed by Awuni, (2002). ND prevalence was significantly higher in females (hens) than males (cocks). This observation differs from a similar study carried out in Nigeria by Jibril et al. (2014), who found higher overall prevalence of ND in male chickens than in females. This could possibly be due to the fact that more hens were sampled in the present study. Males, however, presented higher antibodies titers (GMT-9.0) than females (GMT-8.2) possibly because the sampled males were adults, and this allows for multiple exposures to ND virus in the environment.

The ND prevalence inguinea fowls was different from that observed in the local chicken. The overall prevalence was $24.2 \%$, with females having a prevalence of $25.7 \%$ and males of $22.9 \%$. Although this indicates that there is some activity of the ND virus in guinea fowls, showing that, although significant, it is not as high as in the local chickens, as detected in the present study and that of Oluwayelu et al. (2005).
In the latter,localchickens from households had higher titers than those obtained inthe market. In the market, $48.6 \%$ of guinea fowls were tested positive for ND, being $25.7 \%$ females and $22.9 \%$ males. This is in sharp contrastwith the existing reports of the live market asa hub of ND viral activity (Jibril et al., 2014). The lower ND activity in the live market in Kumasi could be due to lower ND viral activity in the birds sampled.

The range of titers observed in birds from the live bird markets were similar, as most guinea fowls and local chickens presented titers between GMT 5-10, while the mean titers of most of the local chickens sampled in households were higher 10. This suggests that chickens from households possibly experience episodes of ND viral exposure and that the duration of exposure is possiblylonger than those of the live bird market.

\section{CONCLUSION}

This study shows that there is subclinical Newcastle Disease activity in rural poultry in Kumasi and its environs, which could easily escalate to disease state in the event of stress. This is especially true with birds from households, which possibly have repeated ND virus infections, accounting the higher ND titer in these birds compared with those sampled in the live-bird market. Emphasis should therefore place on policies to improve the vaccination campaign against ND in rural poultry, particularly those in different households, with the use of thermostable and better oral or in-feed vaccine delivery systems.

\section{REFERENCES}

Ajani C, Ocobock P. Location: the ashanti lay roots in the Gold Coast. 2012 Available from: https://nd.digication.com/ajani_crosley/Ashanti.

Alders RG, Spradbrow PB. Newcastle disease in village chickens: a field manual. Proceedings of the SADC Workshop Newcastle Disease in Village Chickens; 2000 March 6-9; Maputo (Mozambique): ACIAR/Aus said; 2000. 
Boakye OD, Emikpe BO, Folitse RD, Bonnah SG, Adusei K, Owusu M. Oyebanji vo

Alders R, Spradbow P. Controlling Newcastle disease in village chickens: a field manual [monograph, 82]. Ganberra: Aciar; 2001

Aning $\mathrm{K}$. The structure and importance of the commercial and village based poultry in Ghana [final review report]. Accra; 2006 [cited 2015 Feb 12]. Available from: http://www.fao.org/docs/eims/upload/213723/ agal_poultry review_ghana_aug06.pdf.

Assa M. Poultry production and rural poverty among small-scale farmers in Mzimba district of Malawi. Livestock Research for Rural Development $2012 ; 24(10): 177$

Awuni J. Strategies for the improvement of rural chicken production in Ghana. Accra: Accra Veterinary Laboratory; 2002. [cited 2015 March 02]. Available from: http://www-naweb.iaae.org/nafa/aph/public/4strategies-awuni.pdf

Bensink Z, Spradbow P. Newcastle disease virus strain I2-A prospective thermostable vaccine for use in developing countries. Veterinary Microbiology 1999;68(1/2):131-139.

Jibril A, UmohJ,KabirJ,Bello M, Raji A. Newcastle disease in local chickens of live bird markets and households in Zamfara State, Nigeria. ISRN Epidemiology 2014;1-4. Available from: http://www.hindawi.com/ journals/isrn/2014/513961/

Ghana Statistical Service. Kumasi metropolitan assembly: about this metropolis. 2006. Available from: http://www.kma.ghanadistricts.gov. $\mathrm{gh} / /$ ?arrow $=$ atd \&_=183

\section{Serological Detection of Newcastle Disease Virus Antibodies in Local Chickens and Guinea Fowls in the Area of Kumasi, Ghana}

Ohore OG, Ozegbe PC, Emikpe BO, Okojie V.E. Survey of antibodies to Newscastle disease virus in apparently healthy adult indigenous chickens (Gallus gallusdomesticus) in Ibadan using ELISA. African Journal of Clinical and experimental Microbiology 2003; 3(1):38-40.

Oluwayelu D, Emikpe B, Fagbohun O, Ohore O. Prevalence of antibodies of three avian viral disease in guinea fowls in Ibadan Nigeria. Bulletin of Animal Health and Production in Africa 2005;53:274-276.

Rojendran K, Mohanty S. Comparative economic analysis and constraint in egg production under cage vs. Deep litter system of rearing in India. International Journal of Poultry Science 2003;2(2):153-158.

Spradbrow P. Newcastle disease. Boston: Kluwer Academic Publishers; 1988

SRID/MOFA. Agriculture in Ghana: facts and figures. Accra: Ministry of Food and Agriculture, Statistics Research and Information Directorate; 2010.

VSD - Veterinary Services Directorate. Annual report. Accra: Ministry of Food and Agriculture, Veterinary Services Directorate; 1998.

VSD - Veterinary Services Directorate. Annual report. Accra: Ministry of Food and Agriculture, Veterinary Services Directorate; 2010.

VSD- Veterinary Services Directorate. Annual report. Accra: Ministry of Food and Agriculture, Veterinary Services Directorate; 2011 
